\title{
Article \\ Folate Receptor Beta as a Direct and Indirect Target for Antibody-Based Cancer Immunotherapy
}

\author{
Allison G. Roy 1,2 , J. Michael Robinson ${ }^{3}$, Prannda Sharma 1,2, Alba Rodriguez-Garcia ${ }^{1,2}$, \\ Mathilde A. Poussin 1,2 , Cheryl Nickerson-Nutter ${ }^{4}$ and Daniel J. Powell Jr. ${ }^{1,2, *(D)}$
}

1 Ovarian Cancer Research Center, Department of Pathology and Laboratory Medicine, Perelman School of Medicine, University of Pennsylvania, Philadelphia, PA 19104, USA; smith20a@gmail.com (A.G.R.); pranndas@pennmedicine.upenn.edu (P.S.); rodriguez6@clinic.cat (A.R.-G.); mpoussin@pennmedicine.upenn.edu (M.A.P.)

2 Center for Cellular Immunotherapies, Abramson Cancer Center, University of Pennsylvania, Philadelphia, PA 19104, USA

3 Department of Gynecologic Oncology, Zimmer Cancer Center, New Hanover Regional Medical Center, Wilmington, NC 28401, USA; mike.johnmr@gmail.com

4 Three Lakes Foundation, Northbrook, IL 60062, USA; CNutter@threelakespartners.org

* Correspondence: poda@pennmedicine.upenn.edu; Tel.: +1-215-573-4783; Fax: +1-215-573-5129

\section{check for} updates

Citation: Roy, A.G.; Robinson, J.M.; Sharma, P.; Rodriguez-Garcia, A.; Poussin, M.A.; Nickerson-Nutter, C.; Powell, D.J., Jr. Folate Receptor Beta as a Direct and Indirect Target for Antibody-Based Cancer Immunotherapy. Int. J. Mol. Sci. 2021, 22, 5572. https://doi.org/10.3390/ ijms22115572

Academic Editors: Walter Fiedler and Donald J. Buchsbaum

Received: 19 February 2021

Accepted: 15 May 2021

Published: 25 May 2021

Publisher's Note: MDPI stays neutral with regard to jurisdictional claims in published maps and institutional affiliations.

Copyright: (c) 2021 by the authors. Licensee MDPI, Basel, Switzerland. This article is an open access article distributed under the terms and conditions of the Creative Commons Attribution (CC BY) license (https:/ / creativecommons.org/licenses/by/ $4.0 /)$.

\begin{abstract}
Folate receptor beta $(\mathrm{FR} \beta)$ is a folate binding receptor expressed on myeloid lineage hematopoietic cells. FR $\beta$ is commonly expressed at high levels on malignant blasts in patients with acute myeloid leukemia (AML), as well as on M2 polarized tumor-associated macrophages (TAMs) in the tumor microenvironment of many solid tumors. Therefore, FR $\beta$ is a potential target for both direct and indirect cancer therapy. We demonstrate that FR $\beta$ is expressed in both AML cell lines and patient-derived AML samples and that a high-affinity monoclonal antibody against FR $\beta$ (m909) has the ability to cause dose- and expression-dependent ADCC against these cells in vitro. Importantly, we find that administration of $\mathrm{m} 909$ has a significant impact on tumor growth in a humanized mouse model of AML. Surprisingly, m909 functions in vivo with and without the infusion of human NK cells as mediators of ADCC, suggesting potential involvement of mouse macrophages as effector cells. We also found that TAMs from primary ovarian ascites samples expressed appreciable levels of FR $\beta$ and that $\mathrm{m} 909$ has the ability to cause ADCC in these samples. These results indicate that the targeting of FR $\beta$ using $\mathrm{m} 909$ has the potential to limit the outgrowth of AML in vitro and in vivo. Additionally, m909 causes cytotoxicity to TAMs in the tumor microenvironment of ovarian cancer warranting further investigation of $\mathrm{m} 909$ and its derivatives as therapeutic agents in patients with FR $\beta$-expressing cancers.
\end{abstract}

Keywords: folate receptor beta; acute myeloid leukemia; ovarian cancer; tumor-associated macrophages

\section{Introduction}

Traditionally, cancer treatment has involved various combinations of surgery, radiation, and chemotherapy. However, the emergence of immunotherapies and targeted therapies, particularly in the past two decades, has transformed the treatment of many different types of cancer. Immunotherapy for cancer treatment can be implemented in a variety of different mechanisms including the use of direct antibodies against various immunomodulators or cancer antigens, adoptive therapies like tumor-infiltrating lymphocytes or chimeric antigen receptor (CAR) T cells, as well as cancer vaccines [1]. As immunotherapy research has expanded, the role of the tumor microenvironment in the proliferation and invasiveness of tumors has also become of increasing interest, particularly, the role of tumor-associated macrophages (TAMs).

A promising target for immunotherapy is $\operatorname{FR} \beta$. FR $\beta$ is a member of the folate receptor family, which includes four different folate binding receptors $(\alpha, \beta, \gamma$, and $\delta)$. Folate is essential 
for the biosynthesis of nucleotide bases and for many methylation reactions. Both folate receptor alpha $(\mathrm{FR} \alpha)$ and folate receptor beta $(\mathrm{FR} \beta)$ have been shown to be upregulated in rapidly dividing cells such as those associated with malignancy [2-4]. FR $\alpha$ has been a well-studied target of immunotherapies for over two decades and continues to be optimized with FR $\alpha$ targeted CAR T cells [5,6], an FR $\alpha$-specific antibody (Farletuzumab) [7-12], and FR $\alpha$-specific drug conjugated antibodies (mirvetuximab soravtansine) [13-15] all being evaluated in clinical trials. FR $\beta$ and FR $\alpha$ are both glycosyl phosphatidylinositol (GPI)-bound, share $70 \%$ homology, have a similar affinity for folate, and have a common mechanism of receptor endocytosis-mediated folate uptake [3,4]. While FR $\alpha$ is primarily expressed on epithelial tissues, making it a target in some solid tumors, FR $\beta$ is expressed on myeloid lineage hematopoietic cells [16] and has been shown to be expressed in up to $70 \%$ of cases of acute myeloid leukemia [17] making it a potential therapeutic target.

One of the important myeloid lineage cells that FR $\beta$ is expressed on are TAMs. TAMs can be polarized to an M1 or proinflammatory/anti-tumor subtype or an M2 or immunosuppressive/pro-tumor subtype [18]. TAMs can potentially differentiate into either of these subtypes but the soluble chemokines and cytokines (CCL2, MCSF, IL4, IL10, and TGFB) in the tumor microenvironment favor the M2 polarization [19]. M2 macrophages secrete growth factors, matrix metalloproteases, pro-angiogenic factors, and express inhibitory and immunosuppressive cytokines resulting in tumor growth, angiogenesis, metastasis, and evasion of immune recognition [19]. The presence of TAMs and particularly the increased M2 polarization is associated with a poorer prognosis in many types of cancer including ovarian cancer [20-22]. The presence of M2 TAMs in ovarian cancer is correlated with higher stage [23], higher grade [23,24], and shorter survival [25]. FR $\beta$ has been shown to be a specific marker for M2 polarized macrophages in the tumor microenvironment [26]. m909 is an FR $\beta$-specific human monoclonal antibody that was shown to recognize activated macrophages from rheumatoid patients and to mediate antibody-dependent cell-mediated cytotoxicity (ADCC) [27]. However, its role in oncology is less clear. Using sequences from m909, we previously created an FR $\beta$ targeted CAR T cell approach that demonstrated activity in both in vitro and in vivo models of AML without evidence of hematopoietic stem cell toxicity [28,29]. Based on the effectiveness of these FR $\beta$ CAR $\mathrm{T}$ cells in the preclinical setting and the improved ease of production and administration of direct antibody therapies compared to CAR T cells, we hypothesized that the parental anti-FR $\beta$ antibody (m909) could be a potential treatment for AML by recognizing FR $\beta$ on AML blast cells and mediating the toxicity of these cells. Additionally, an antibody against FR $\beta$ could be used to improve the treatment of solid tumors such as ovarian cancer by eliminating immunosuppressive, pro-tumorigenic M2 macrophages in the microenvironment. Therefore, we sought to demonstrate the potential of targeting FR $\beta$ with m909 as both direct treatment of AML and indirect treatment of ovarian cancer.

\section{Results}

\section{1. $m 909$ Detects FR $\beta$ Expression and Can Mediate ADCC of AML Cell Lines}

FR $\beta$ surface expression was evaluated on engineered cell lines and AML cell lines. m909 was biotinylated to allow for detection of FR $\beta$ surface expression on the various cell lines via flow cytometry. The expression of FR $\beta$ was first analyzed on engineered and parental $\mathrm{CHO}$ cell lines. The parental CHO-K1 cells, used as a control, did not express detectable FR $\beta$ while all CHO-FR $\beta$ cells, had detectable surface FR $\beta$ expression (Figure 1a). To validate the ability of $\mathrm{m} 909$ to cause FR $\beta$-targeted ADCC, CHO-FR $\beta$ and CHO-K1 cells expressing green fluorescent protein and luciferase (GFP-Luc) were co-cultured with NK cells in the presence of m909. Cytotoxicity was determined by residual luciferase expression after approximately $24 \mathrm{~h}$. ADCC studies performed at $0.1 \mu \mathrm{g} / \mathrm{mL}, 1 \mu \mathrm{g} / \mathrm{mL}$, and $10 \mu \mathrm{g} / \mathrm{mL}$ antibody concentrations showed significant cytotoxicity of $\mathrm{CHO}-\mathrm{FR} \beta$ cells even at the lowest concentration of antibody. A $56.9 \%$ specific cytotoxicity at $0.1 \mu \mathrm{g} / \mathrm{mL}$ and $72.4 \%$ specific cytotoxicity at $10 \mu \mathrm{g} / \mathrm{mL}$ of m909 was observed. There was no evidence of substantial cytotoxicity in CHO-K1 cells after m909 treatment at any antibody concentration (Figure 1b). 
a

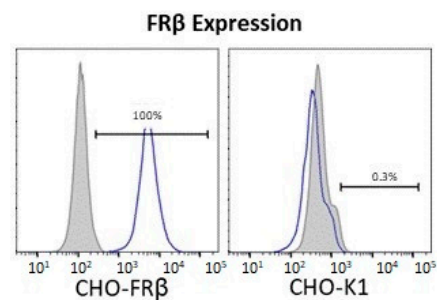

b

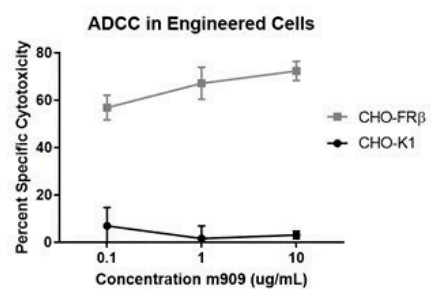

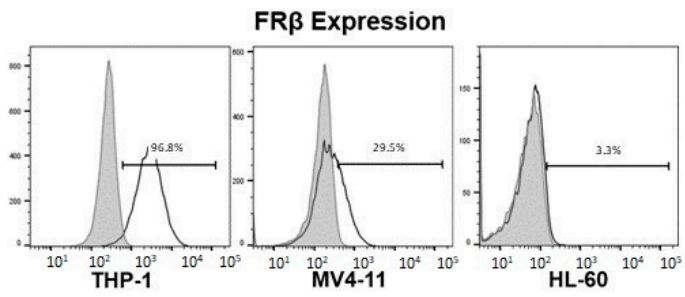

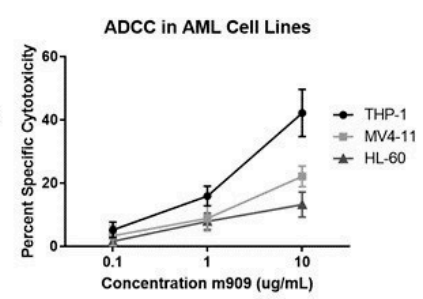

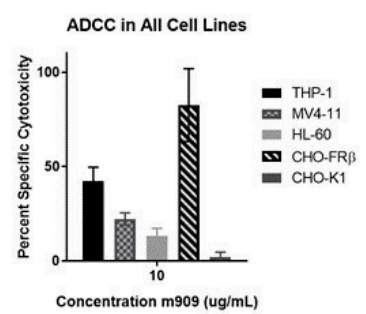

Figure 1. FR $\beta$ expression analysis and targeting using m909 antibody. (a) FR $\beta$ is expressed at $100 \%$ on the engineered cell line (CHO-FR $\beta)$. No expression is detected in the parental control (CHO-K1). (b) Antibody-dependent cytotoxicity assay (ADCC) with CHO-FR $\beta$ cells, NK cells at E:T ratio 10:1 and increasing doses of m909. Specific cytotoxicity is calculated by subtracting the percentage of cell death with no antibody. Representative results from one of two independent experiments with triplicate samples in each experiment are shown. (c) FR $\beta$ expression on immortalized AML cell lines THP-1, MV4-11, and HL-60. (d) ADCC assay at increasing doses of m909 for AML cell lines incubated with NK cells at E:T of 10:1 demonstrating a dose-dependent and expression-dependent response. Representative results from one of three independent experiments with triplicate samples per concentration and cell type are shown. (e) Specific cytotoxicity for ADCC assay for each cell line at $10 \mu \mathrm{g} / \mathrm{mL}$ m909 using NK cells from the same donor performed with triplicate samples. All error bars represent standard deviation.

The expression of FR $\beta$ and the induction of ADCC by m909 in immortalized human AML cell lines were then evaluated to understand the impact of m909 on cells with natural expression of FR $\beta$. The human AML cell line THP-1 expressed high levels of FR $\beta$ while MV4-11 cells expressed a moderate level, and HL-60 cells had minimal to no detectable expression of FR $\beta$ (Figure 1c). These cell lines were transduced for GFP-Luc expression and ADCC assays were performed in a similar fashion to that for the $\mathrm{CHO}-\mathrm{K} 1$ and $\mathrm{CHO}-\mathrm{FR} \beta$ cells. THP-1 cells were sensitive to m909-mediated cytotoxicity with $42.2 \%$ cell killing observed at the highest antibody concentration while $22.1 \%$ specific cytotoxicity was achieved against MV4-11 cells, and 13.2\% against HL-60 cells. All cell lines demonstrated a dose-dependent response. (Figure 1d). Using NK cells from the same donor, the increase in specific cytotoxicity for all cell lines also correlated with increasing surface expression of FR $\beta$ (Figure 1e).

\section{2. m909-Mediated Cytotoxicity of AML Cells Relies upon ADCC}

Having determined that $\mathrm{m} 909$ can effectively induce FR $\beta$-targeted cell death through ADCC, we investigated whether $\mathrm{m} 909$ could mediate cell death by alternative mechanisms. We first assessed whether the presence of the antibody in the absence of effector cells affected the growth of FR $\beta$-expressing cells in culture. CHO-FR $\beta, \mathrm{CHO}-\mathrm{K} 1, \mathrm{THP}-1, \mathrm{MV} 4$ 11 , and HL-60 cells were cultured in the presence or absence of $\mathrm{m} 909$ and growth curves were plotted. No significant differences were observed in overall cell growth in the presence or absence of m909 (Figure 2a). 
a
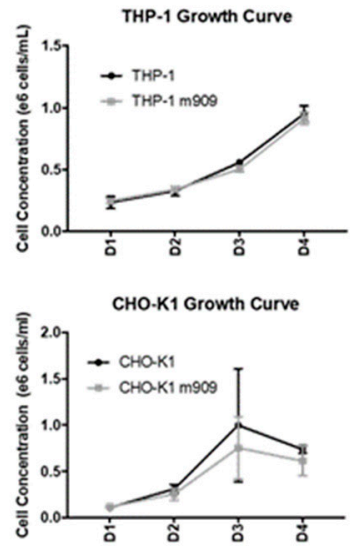

b

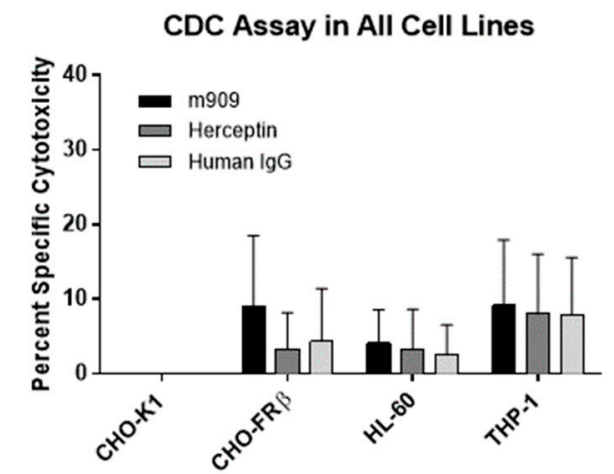

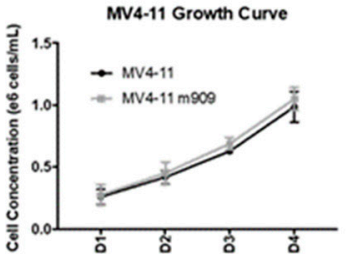
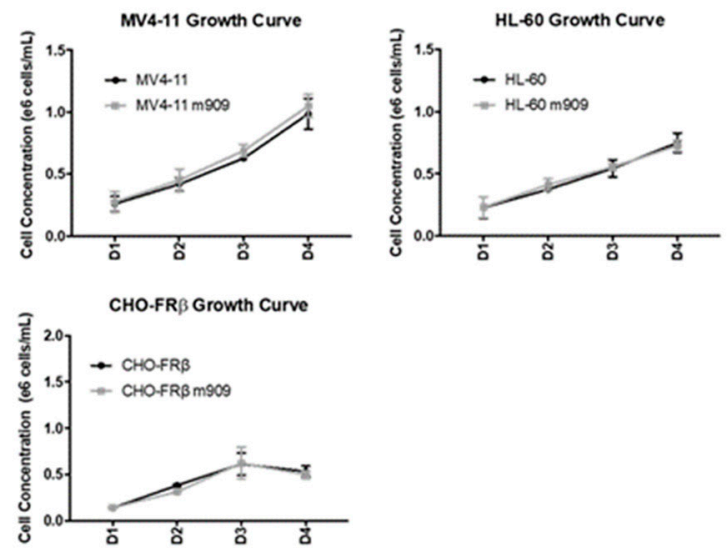

c

Early and Late Apoptosis at $24 \mathrm{hrs}$ with $\mathrm{m} 909$

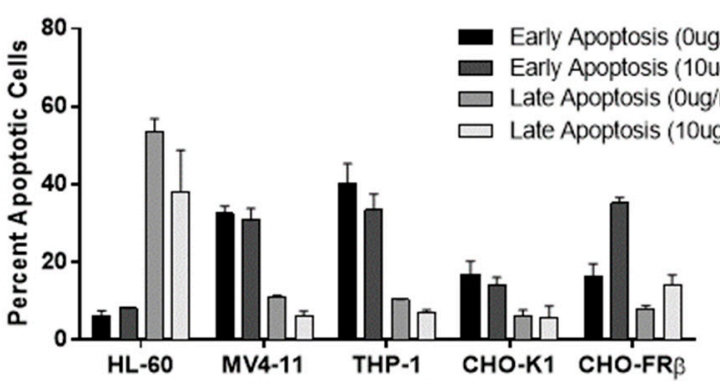

Figure 2. Evaluating additional mechanisms of action for m909 antibody. (a) Cells grown in the presence or absence of $10 \mu \mathrm{g} / \mathrm{mL}$ of $\mathrm{m} 909$ over time in days. (b) Complement-dependent specific cytotoxicity for cell lines in presence of $10 \mu \mathrm{g} / \mathrm{mL}$ of m909, Herceptin, or human IgG1 with human serum. Samples tested in triplicate. (c) Percentage of cells with early and late markers of apoptosis after $24 \mathrm{~h}$ of incubation with and without $10 \mu \mathrm{g} / \mathrm{mL} \mathrm{m} 909$. All error bars represent standard deviation.

Next, we examined the effect of m909-directed complement-dependent cytotoxicity (CDC) on FR $\beta$ high and low expressing cell lines transduced with GFP-fLuc. In addition to m909, cells were treated with non-specific antibodies, Herceptin and Human IgG1, as controls. m909 did not mediate increased CDC against the various cell targets compared to control antibodies, as determined by a paired t-test (Figure $2 \mathrm{~b}$ ). The lack of cytotoxicity observed in the CDC experiments indicates that $\mathrm{m} 909$ appears to function independently of the need for complement activation.

Finally, we evaluated the potential for $\mathrm{m} 909$ to cause direct cell apoptosis, albeit this seemed an unlikely method of action for m909 based upon cell growth results. After culturing the various cell lines in the presence or absence of $10 \mu \mathrm{g} / \mathrm{mL}$ of $\mathrm{m} 909$ for a $24-\mathrm{h}$ incubation, the percentage of cells in early apoptosis and those in late apoptosis were determined and compared. For some cell lines, greater than $50 \%$ of the cells showed signs of apoptosis, however, there were no significant differences between cells treated with m909 and the untreated cells across all the cell lines (Figure 2c), indicating that $\mathrm{m} 909$ binding to FR $\beta$ on the cancer cell surface does not mediate direct cell apoptosis in vitro.

\subsection{AML Patient Samples Express FR $\beta$ and $m 909$ Can Cause ADCC of These Samples}

In order to assess the applicability of m909 to AML patients rather than just immortalized cell lines, we also studied the expression of FR $\beta$ in patient samples with various subtypes of AML. From previous expression studies in our lab and by others $[3,17,30]$, it has been demonstrated that M4 and M5 subtypes of AML tend to express the highest levels of FR $\beta$. However, in this study, the majority of samples expressed at least moderate levels of FR $\beta$ with an average of $21.9 \%$ expression and a range of $2.0-60.1 \%$ among the 12 samples 
(Figure 3a). Due to the inability to transduce these cells with GFP-Luc to perform ADCC in the same manner as the immortalized cell lines, we developed a method using flow cytometry to detect the number of viable cells remaining. We first validated a flow-based assay using THP- 1 cells as targets. THP- 1 cells were plated in the presence of the indicated concentrations of m909 and co-cultured overnight with NK cells. Subsequent staining with fluorophore-labeled anti-CD33 was used to identify the THP-1 cells and biotinylated $\mathrm{m} 909$ was used to detect FR $\beta$. The cells were then analyzed using flow cytometry for the number of live $\mathrm{CD} 33+$ and $\mathrm{CD} 33+/ \mathrm{FR} \beta+$ cells at each concentration. Treatment resulted in a reduction in CD33+ cells of $48.1 \%$ at $0.1 \mu \mathrm{g} / \mathrm{mL}, 67.8 \%$ at $1 \mu \mathrm{g} / \mathrm{mL}$, and $82.2 \%$ at $10 \mu \mathrm{g} / \mathrm{mL}$ of $\mathrm{m} 909$. When staining for CD33+/FR $\beta+$ cells, the decrease was even greater with $87.6 \%$ at $0.1 \mu \mathrm{g} / \mathrm{mL}, 93.4 \%$ at $1 \mu \mathrm{g} / \mathrm{mL}$, and $94.2 \%$ at $10 \mu \mathrm{g} / \mathrm{mL}$ (Figure $3 \mathrm{~b}$ ).

a
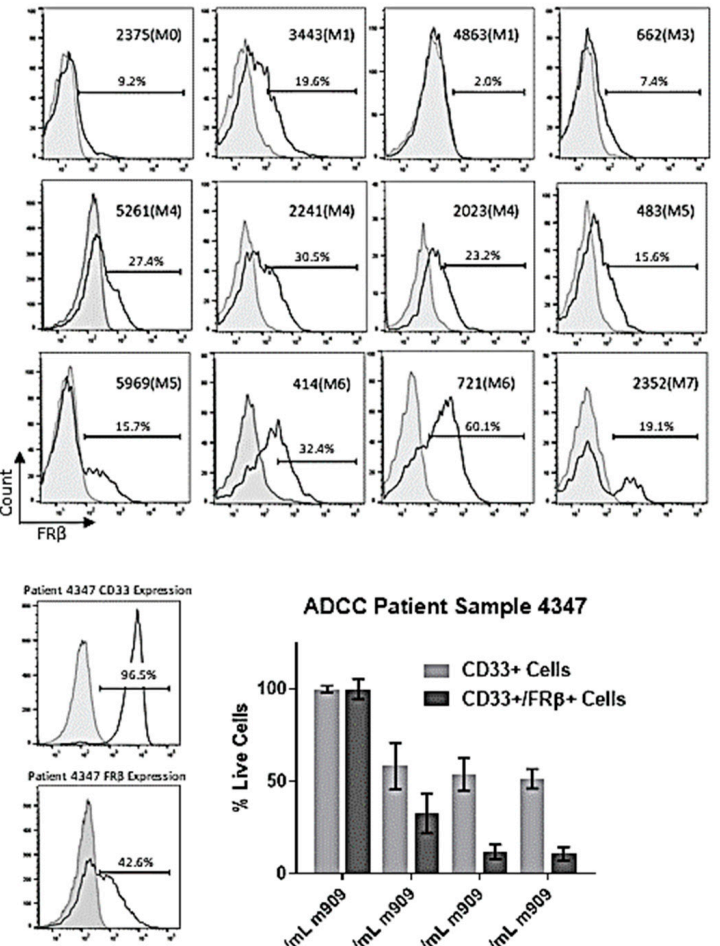

b

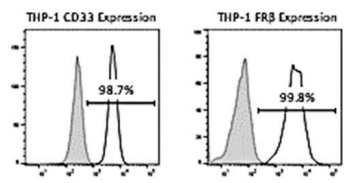

ADCC THP-1 Cells

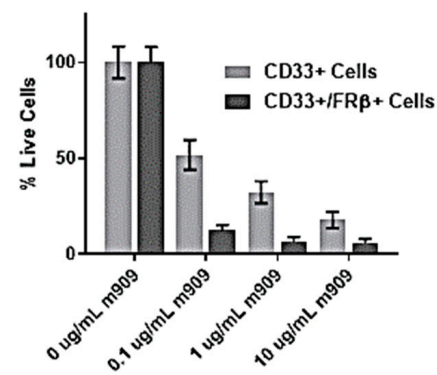

Figure 3. Activity of m909 against primary patient AML samples. (a) FR $\beta$ expression on patient samples with various subtypes of AML. (b) Expression of CD33 and FR $\beta$ in THP- 1 cells and ADCC by flow using THP- 1 cells demonstrates efficacy with dose-dependent response. (c) CD33 and FR $\beta$ expression data for patient sample 4347. ADCC data for patient sample 4347 showing average from two separate experiments with triplicate samples. All graphs were normalized to wells with $0 \mu \mathrm{g} / \mathrm{mL}$ of m909. Error bars represent standard deviation.

Next, a patient sample with high levels of CD33 expression and moderate levels of FR $\beta$ expression was selected for this method of analysis. Following treatment with m909, the patient sample showed a statistically significant reduction of the amount of live CD33+ cells of $41.7 \%$ at $0.1 \mu \mathrm{g} / \mathrm{mL}, 46.0 \%$ at $1 \mu \mathrm{g} / \mathrm{mL}$, and $48.6 \%$ at $10 \mu \mathrm{g} / \mathrm{mL}$, compared to the untreated control. The reduction in CD33+/FR $\beta+$ cells was even greater with $67.2 \%$ at $0.1 \mu \mathrm{g} / \mathrm{mL}, 88.1 \%$ at $1 \mu \mathrm{g} / \mathrm{mL}$, and $89.2 \%$ at $10 \mu \mathrm{g} / \mathrm{mL}$, demonstrating a concentrationdependent effect on cytotoxicity mediated by m909 (Figure 3c).

\section{4. $m 909$ Reduces Tumor Growth in a Human AML Xenograft Model}

Our in vitro results clearly indicate that ADCC appears to be the most efficient mechanism by which $\mathrm{m} 909$ causes cytotoxicity in cell lines as well as against primary AML cells expressing FR $\beta$. Therefore, we tested the cytotoxic activity of m909 in vivo using an 
NOD/SCID/ $\gamma$ chain - / - (NSG) xenograft model of AML in combination with NK cell transfer. Each mouse received an intravenous (IV) injection of two million GFP-fLuc expressing THP-1 cells, followed two days later by a single IV injection of two million activated NK cells or phosphate-buffered saline (PBS) in combination with intraperitoneal (IP) injection of $100 \mu \mathrm{g}$ of m909 or PBS. IP injection of m909 was repeated every 2-3 days for 10 doses and tumor growth was longitudinally monitored using bioluminescence imaging. A statistically significant decrease in tumor progression was observed on day 65 in the $100 \mu \mathrm{g} \mathrm{m909} \mathrm{plus} \mathrm{NK} \mathrm{cell} \mathrm{group,}$ compared to the PBS group, using two-way ANOVA (Figure 4a). Notably, the $100 \mu \mathrm{g}$ m909 alone group also had significantly lower tumor volume compared to the PBS group, indicating that the m909 antibody activity in the xenograft model was NK cell-independent. The mean difference in tumor bioluminescence between the PBS group and both the $100 \mu \mathrm{g}$ m909 group and $100 \mu \mathrm{g}$ m909 plus NK group was significant, with a mean difference of $2.59 \times 10^{9}(95 \% \mathrm{CI}$ $\left.1.61 \times 10^{9}-3.57 \times 10^{9}, p<0.0001\right)$ and $2.05 \times 10^{9}\left(95 \%\right.$ CI $\left.1.12 \times 10^{9}-2.99 \times 10^{9}, p<0.0001\right)$ respectively. There was no significant difference between the two treatment groups. Thus, since NSG mice lack T cells, B cells, and NK cells, these results indicate that NK cells were not necessary for the anti-tumor effect of $\mathrm{m} 909$ in vivo. (Figure 4a).

a
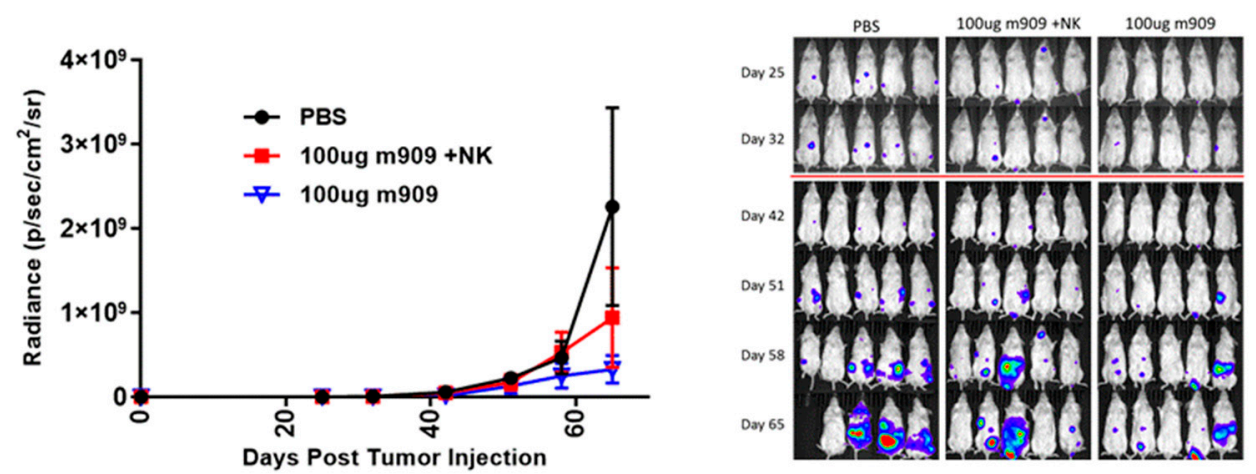

b
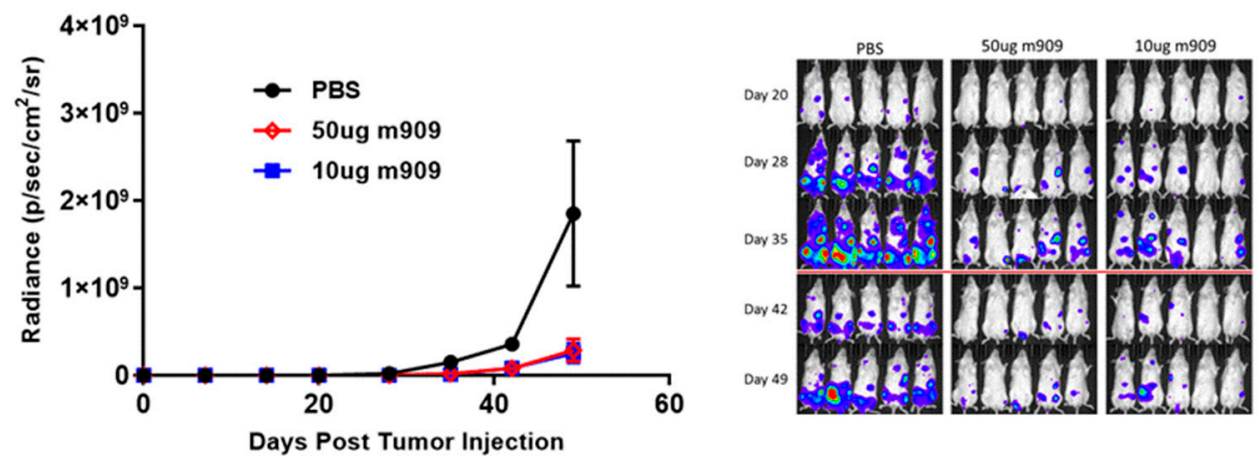

Figure 4. Preclinical activity of m909 against THP-1 tumors in vivo. (a) Mice were injected with 2 $\times 10^{6}$ THP-1 cells expressing GFP-fLuc on day 0 and imaged weekly. They were treated with IP injection starting on day 2 every $2-3$ days thereafter for 10 doses with $100 \mu \mathrm{g}$ m909 or PBS. The NK group received activated NK cells on day 2 . The average maximum radiance of each group at each measurement time point is shown in the graph. Significant differences were identified on day 65 between the treatment groups and the PBS group. (b) Mice were injected with $2 \times 10^{6}$ THP-1 cells expressing GFP-fLuc on day 0 and received antibody via IP injection starting on day 2 and every 2-3 days thereafter at the respective doses for a total of 10 doses. Significant differences were identified between the treatment groups and the PBS group on day 49. All error bars represent standard error. Red lines on images indicate a change in exposure time.

The efficacy of m909 against AML in vivo was next tested at decreased doses of m909 in the absence of NK cells. GFP-fLuc expressing THP-1 cells were injected IV at day 0. $\mathrm{m} 909$ was then injected at $10 \mu \mathrm{g}$ or $50 \mu \mathrm{g}$ on day 2 and thereafter every $2-3$ days for a total of 10 doses. Tumor progression was monitored by bioluminescence imaging. Both 
doses of m909 showed a statistically significant reduction in tumor growth compared to the control group on day 49 (Figure $4 \mathrm{~b}$ ). The mean difference in bioluminescence between the PBS group and the $50 \mu \mathrm{g}$ m909 group was $1.25 \times 10^{9}\left(95 \% \mathrm{CI} 6.65 \times 10^{8}-1.84 \times 10^{9}\right.$, $p<0.001)$ and between the PBS group and the $10 \mu \mathrm{g}$ m909 group was $1.29 \times 10^{9}(95 \% \mathrm{CI}$ $\left.6.99 \times 10^{8}-1.87 \times 10^{9}, p<0.001\right)$. There was no significant difference between the $10 \mu \mathrm{g}$ and $50 \mu \mathrm{g}$ doses by day $49(p=0.989)$. Additionally, a similar experiment was conducted to compare treatment with PBS, $50 \mu \mathrm{g}$ m909, and $100 \mu \mathrm{g}$ of a non-specific antibody Herceptin. There was a significant tumor reduction in the mice treated with $50 \mu \mathrm{g}$ m909 compared to PBS. In contrast, no difference in tumor growth was observed between the mice that received Herceptin and those that received PBS (Supplemental Figure S1).

\subsection{Mechanisms for In Vivo Reduction of AML Tumor Growth}

The previous experiments demonstrated that the addition of NK cells did not affect the ability of m909 to impact tumor growth and that even lower doses of m909 were effective against tumor growth. Therefore, we conducted studies to identify additional mechanistic pathways that could potentially be responsible for the suppression of tumor outgrowth in vivo. To determine whether m909, the anti-human FR $\beta$ specific antibody, could be binding to mouse cells, experiments were run to assess cross-reactivity. ID8 mouse cells previously engineered to express mouse $\mathrm{FR} \beta(\mathrm{mFR} \beta$ ) by lentiviral transduction were stained using anti-mouse FR $\beta$ (CL10) [31] or the anti-human FR $\beta$ (m909) and analyzed by flow cytometry. The CL10 antibody stained ID8-FR $\beta$ cells, while m909 did not, confirming a lack of cross-reactivity (Figure 5a). Our in vitro assays using human cells indicate that $\mathrm{m} 909$ itself does not appear to reduce cell growth, induce apoptosis, or initiate complement-dependent cytotoxicity (CDC) at a significant level. In addition, $\mathrm{CDC}$ is not likely to function in vivo as NSG mice lack C5 complement and therefore the ability to create the membrane attack complexes necessary for cytotoxicity through the complement cascade [32].

We next investigated whether another innate element in the NSG mice affects antibody function. While NSG mice lack NK cells, T cells, or B cells, they do harbor macrophages, albeit with impaired function [33]. We, therefore, investigated whether these residual mouse macrophages play a role in $\mathrm{m} 909$ activity in vivo. The drug liposomal clodronate depletes macrophages in in vivo mouse models [32-37]. Prior to introducing liposomal clodronate to mice, we evaluated the impact of liposomal clodronate on the THP-1 tumor cells in vitro. THP-1 cells were co-cultured with various doses of liposomal clodronate for 24,48 , and $72 \mathrm{~h}$ and then analyzed for cell death in a luciferase assay (Figure $5 \mathrm{~b}$ ). As the concentration of liposomal clodronate increased above $0.1 \mu \mathrm{g} / \mu \mathrm{L}$, there was a significant increase in cell death. At $0.5 \mu \mathrm{g} / \mu \mathrm{L}, 38.5 \%$ of the cells were dead after $24 \mathrm{~h}$. This increased to $59.9 \%$ at $48 \mathrm{~h}$ and sustained at $58.1 \%$ at $72 \mathrm{~h}$. Nevertheless, this in vitro study may not reflect the function of liposomal clodronate in vivo because clodronate released from dead macrophages or residing in the culture medium cannot diffuse from the medium whereas in vivo it has a very short half-life as it is rapidly cleared by the kidneys [30,31].

We used liposomal clodronate as an agent of macrophage depletion in NSG mice and treated them with $50 \mu \mathrm{g}$ m909, $50 \mu \mathrm{g}$ m909 plus liposomal clodronate, or liposomal clodronate alone to control for the impact that liposomal clodronate might have on THP-1 cells. Dosing of liposomal clodronate was determined from preliminary trials as well as a literature search [35-40]. Mice were treated with $200 \mu \mathrm{L}$ IV and $100 \mu \mathrm{L}$ IP of liposomal clodronate one day (day -1) prior to IV injection of 2 million THP-1 tumor cells (day 0 ) and then treated with $25 \mu \mathrm{L}$ doses every 5 days for the duration of antibody injections. Blood draws were performed on five mice from each group on day 1 (prior to m909 administration) and the blood was stained for macrophage markers CD11b+ and F4-80. In the absence of liposomal clodronate treatment, mice had an average of $30.6 \pm 8.8 \%$ macrophages in the PBS control group and $27.7 \pm 6.7 \%$ in the $50 \mu \mathrm{g}$ m909 treated group. A lower frequency of macrophages was detected in the liposomal clodronate groups with an average of $10.4 \pm 1.6 \%$ in the liposomal clodronate alone group, and $12.1 \pm 3.6 \%$ in the liposomal clodronate plus $50 \mu \mathrm{g} \mathrm{m} 909$ group. This resulted in a statistically significant 
decrease in the percentage of macrophages in the groups that received liposomal clodronate, compared to those that did not. At this time point (day 1), none of the groups had yet received the antibody, therefore no experimental difference existed in the groups that went on to receive $\mathrm{m} 909$ from those that did not. This assay was repeated on day 21 to detect macrophage levels and the difference in the percentage of macrophages was no longer statistically significant. The PBS group had $33.2 \pm 6.3 \%$ macrophages and the $50 \mu \mathrm{g} \mathrm{m} 909$, liposomal clodronate, and liposomal clodronate plus $50 \mu \mathrm{g} \mathrm{m} 909$ groups had $30.0 \pm 2.1 \%, 23.5 \pm 12.0 \%$, and $31.2 \pm 6.8 \%$ respectively (Figure $5 \mathrm{c}$ ), indicating that the $25 \mu \mathrm{L}$ booster doses given to the mice every 5 days did not sustain the suppression of the macrophage population.

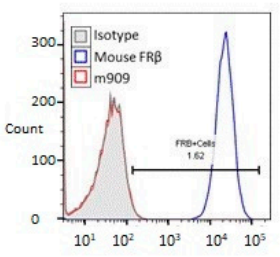

d b

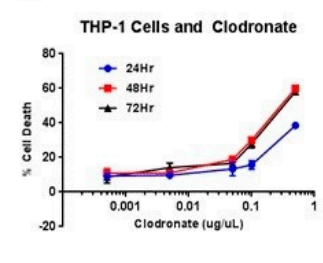

C

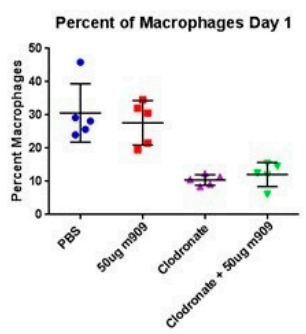

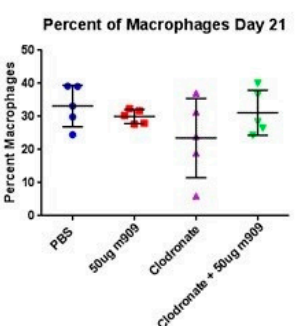
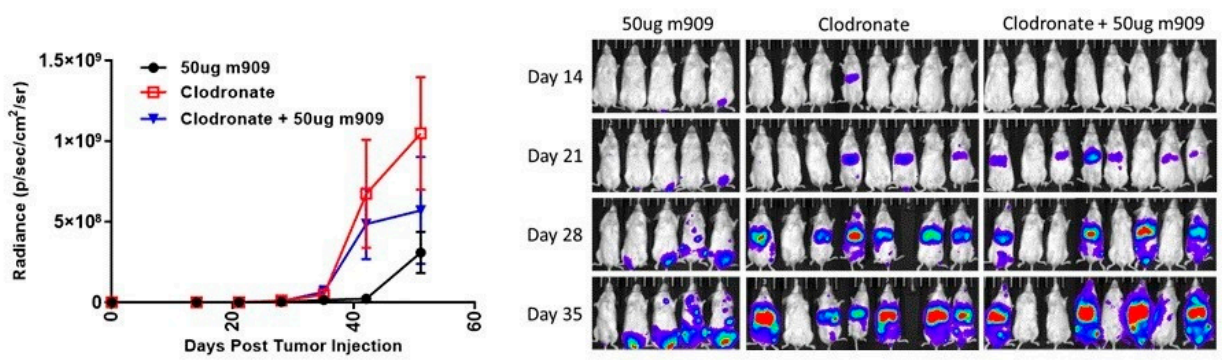

Figure 5. m909 activity in vivo after macrophage depletion. (a) m909 does not cross react with mouse FR $\beta$. (b) In vitro co-culture of THP-1 cells in the presence of liposomal clodronate at different concentrations for 24,48 , and 72 h shows increasing toxicity at higher concentrations. Error bars represent standard deviation. (c) Blood draws from five mice in each treatment group demonstrate the percentage of macrophages on day 1 and day $21.300 \mu \mathrm{L}$ of liposomal clodronate was given on day -1 and repeated small dose of $25 \mu \mathrm{L}$ every 5 days until the end of antibody dosing. Error bars represent standard deviation. (d) Mice injected with $2 \times 10^{6} \mathrm{THP}-1$ cells on day 0 and then treated with m909 for 10 doses starting day 2 as in previous experiments as well as liposomal clodronate. m909 still has an impact on tumor growth even in the presence of liposomal clodronate. Error bars represent standard error.

The mice also underwent bioluminescent imaging to analyze tumor growth. The tumors in the groups that received liposomal clodronate grew more than in the $50 \mu \mathrm{g} \mathrm{m} 909$ alone group indicating that THP-1 cell viability was not inhibited by liposomal clodronate, in contrast to the in vitro findings. Of note, the mean tumor bioluminescence in the group that received liposomal clodronate plus $50 \mu \mathrm{g} \mathrm{m909} \mathrm{was} \mathrm{higher} \mathrm{than} \mathrm{the} 50 \mu \mathrm{g} \mathrm{m} 909$ alone group at days 35,42 , and 51 . This trended toward a significant difference between the 50 $\mu \mathrm{g}$ m909 group and the liposomal clodronate plus $50 \mu \mathrm{g} \mathrm{m} 909$, particularly at day 42 with a mean difference of $5.27 \times 10^{8}(p=0.069)$. However, this significance was not maintained at day $51(p=0.483)$ (Figure $5 \mathrm{~d}$ ). The data were compared using two-way ANOVA analysis.

There was also a statistically significant increase in tumor growth in the liposomal clodronate alone group, compared to the $50 \mu \mathrm{g}$ m909 alone group at days 35, 42, and 51 . The mean difference in tumor bioluminescence was $6.49 \times 10^{8}(p=0.009)$ on day 42 and $7.38 \times 10^{8}(p=0.003)$ on day 51. The addition of $50 \mu \mathrm{g} \mathrm{m909}$ to the mice treated with liposomal clodronate showed a trend toward improvement which was, however, not statistically significant. Interestingly, almost all mice in the liposomal clodronate group 
developed tumors while the small tumors observed on day 21 in the clodronate plus $50 \mu \mathrm{g}$ m909 group decreased, demonstrating the potential efficacy of the antibody correlating with the return of the macrophage population (Figure 5d). There was one mouse in each of the groups that did not appear to grow any tumor. The exact role that mouse macrophages are playing in the efficacy of the m909 antibody remains uncertain but there is clearly additional tumor growth when macrophages are depleted.

\subsection{Tumor-Associated Macrophages in Ovarian Ascites Samples Express FR $\beta$}

Having established that 909 can cause ADCC in vitro against primary AML cells and in vivo in a humanized mouse model, we also examined the application against the tumor microenvironment targeting tumor-associated macrophages (TAMs) in solid tumors using ovarian cancer. We analyzed 15 individual primary ovarian ascites samples for the percentage of TAMs in each sample as well as for the expression of FR $\beta$ in the total sample and then specifically on TAMs by flow cytometry. TAMs were defined by the CD14 and $\mathrm{CD} 11 \mathrm{~b}$ double-positive population in the samples. Overall, the ascites samples contained an average of $23.3 \%$ TAMs with a range of $2.3-58.6 \%$. (Figure $6 a$ ). In the total samples, FR $\beta$ expression was found on an average of $20.8 \%$ of the cells with a range of $3.7-45.1 \%$. When samples were gated for TAMs, the average expression of FR $\beta$ was $61.6 \%$ with a range of $19.1-84.9 \%$ (Figure $6 \mathrm{~b}$ ). The majority of the FR $\beta$ expression in these samples was noted to be on the TAMs.

\section{7. $m 909$ Can Cause ADCC of TAMs in Primary Ascites Samples}

Next, we explored the ability of m909 to cause ADCC of TAMs in primary ascites samples. Two ovarian ascites samples were selected that contained a high level of TAMs, which were sorted from samples using CD11b magnetic beads to isolate the positive population. ADCC by flow was then performed using a similar technique as for AML samples. Patient sample 1572 had $85.8 \%$ expression of FR $\beta$ on TAMs and when ADCC assay was performed using $\mathrm{m} 909$ at $10 \mu \mathrm{g} / \mathrm{mL}$ this resulted in a $66.1 \%(95 \%$ CI $36.4-$ $95.7 \%, p<0.001$ ) decrease in the number of live FR $\beta$ positive TAMs (Figure $7 a$ ). We then expanded the concentration ranges to analyze activity against sample 1585, which had an FR $\beta$ expression of $84.8 \%$. There was a clear dose-dependent response with a significant decrease compared to control at all antibody concentrations. There was a decrease in the percentage of live TAMs of $38.5 \%$ (95\% CI $27.8-49.3 \%, p<0.001$ ), $64.3 \%$ (95\% CI $53.6-75.0 \%$, $p<0.001)$, and $74.1 \%(95 \% \mathrm{CI} 63.4-84.9 \%, p<0.001)$ at $0.1 \mu \mathrm{g} / \mathrm{mL}, 1 \mu \mathrm{g} / \mathrm{mL}$, and $10 \mu \mathrm{g} / \mathrm{mL}$ m909 respectively demonstrating the potential of m909 to reduce TAMs in the tumor microenvironment of ovarian cancer (Figure 7b). 
a

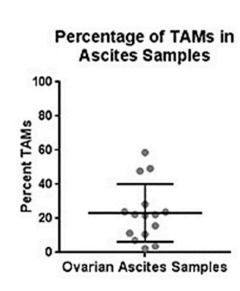

c

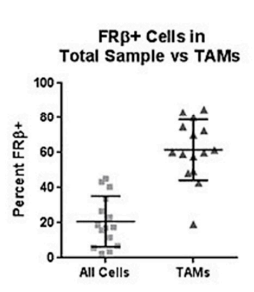

FRß Expression on Total Sample

b
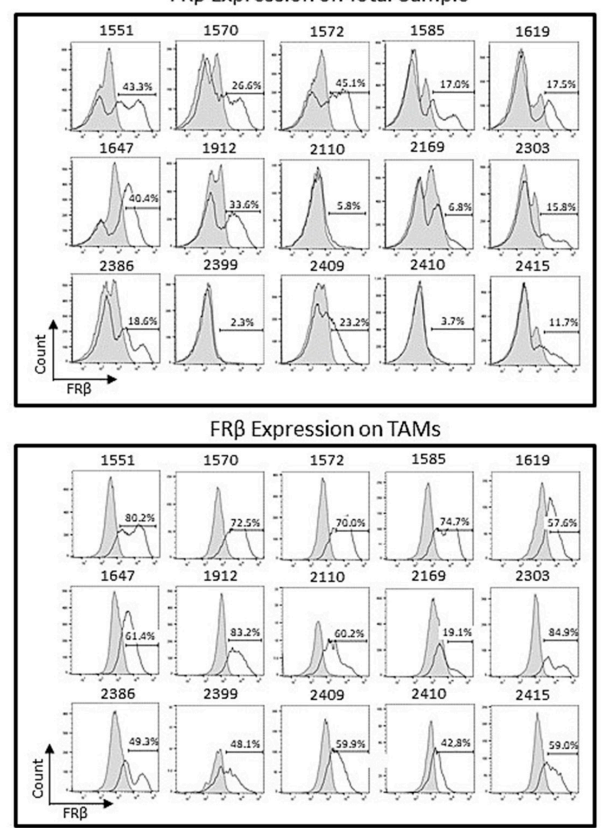

Figure 6. Tumor associated macrophages in ovarian cancer ascites samples and expression of FR $\beta$. (a) Percentage of TAMs making up each of the fifteen ovarian ascites samples as determined by CD11b and CD14 double-positive population with an average of $23.3 \%$. (b) Flow plots showing the expression of FR $\beta$ in each of the 15 total ascites samples compared to expression on TAMs in the sample. (c) Comparison of the average expression of FR $\beta$ in the total sample (20.8\%) versus expression on TAMs (61.6\%).

a
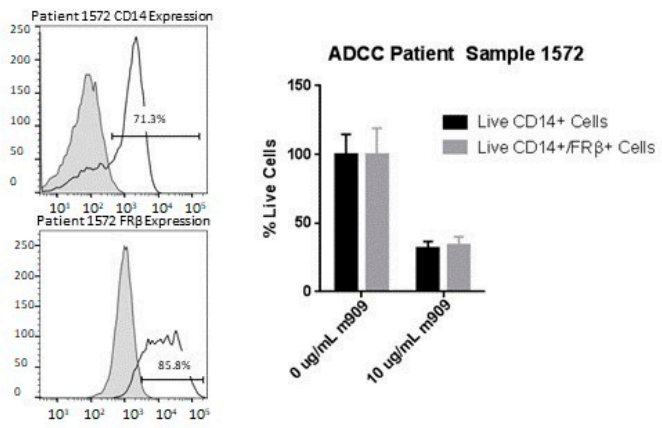

b
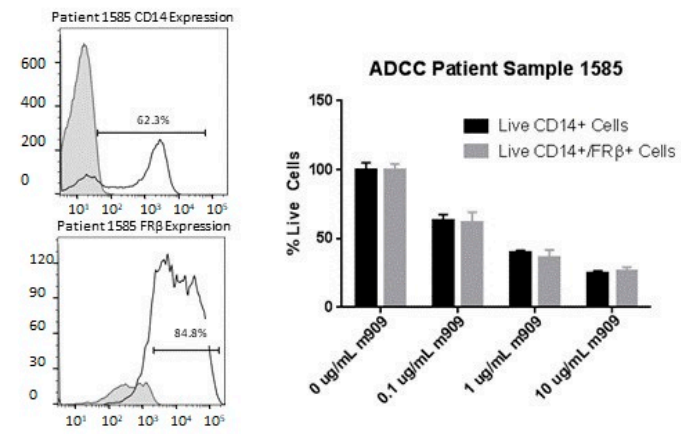

Figure 7. Expression of FR $\beta$ and ADCC on primary ovarian ascites samples. (a) CD14 and CD14/FR $\beta$ expression data for patient sample 1572. ADCC data for patient sample 1572 showing a significant decrease in live FR $\beta$ expressing cells. (b) CD14 and CD14/FR $\beta$ expression on patient sample 1585. ADCC data for patient sample 1585 showing a dose-dependent response to $\mathrm{m} 909$ administration. All samples were tested in triplicate and all graphs were normalized to wells with 0 $\mu \mathrm{g} / \mathrm{mL}$ of m909. Error bars represent standard deviation. 


\section{Discussion}

Acute myeloid leukemia and ovarian cancer are both deadly diseases with a poor overall prognosis. AML is one of the most common types of leukemia with a five-year survival of only $25 \%$ [41]. Initial treatment of AML with induction chemotherapy has not changed significantly in the past 30 years and $60-85 \%$ of those under age 60 will achieve complete response while only $40-60 \%$ of older patients will [42]. Following remission, patients receive consolidation chemotherapy and/or hematopoietic cell transplant that achieves cure in $60-70 \%$ of those with favorable risk factors. However, those with intermediate or poor risk profiles only have a $10-15 \%$ chance of cure so new treatments are needed to improve these outcomes [42]. Similarly, ovarian cancer is the deadliest gynecologic cancer and there are no good screening tools, resulting in patients typically being diagnosed at stage III or IV disease where the five-year survival is $29 \%$ [41]. The majority of patients will respond to initial chemotherapy. However, like AML, approximately $80 \%$ will recur, making the development of new treatment strategies imperative.

In this study, we validated m909, an anti-human FR $\beta$ antibody that demonstrates in vitro efficacy via ADCC against AML cells in a dose- and expression-dependent manner for both established cell lines and primary acute myeloid leukemia cells. m909 does not appear to cause significant cytotoxicity in vitro by any of the other mechanisms analyzed including CDC, apoptosis, and growth inhibition. We further explored the efficacy of m909 in a mouse model of AML and found that tumor growth is significantly reduced by m909. The exact mechanism by which m909 functions to inhibit tumor growth in vivo is still unclear. Although NK cells were required in vitro for efficacy, interestingly, administration of m909 to tumor-bearing NSG mice had similar efficacy in reducing the tumor growth over time with and without the infusion of NK cells. NSG mice lack the majority of immune cell elements including T cells, B cells, NK cells, and complements which make them an excellent resource for the development of humanized models. However, macrophages and dendritic cell populations are still present in the NSG model, although the NOD genetic background does result in a reduction in function for these populations in vivo [43]. This suggests a possible role of innate effector cells, such as mouse macrophages, as mediators of ADCC in our in vivo model.

Our results demonstrate that there is no cross reactivity between the anti-human FR $\beta$ antibody and mouse FR $\beta$ since m909 did not bind to mouse ID8 cells with engineered expression of mouse FR $\beta$. This would also indicate that mouse macrophages are unlikely to interact with m909 via the human FR $\beta$-binding portion of the antibody. However, reactivity between the Fc region of $\mathrm{m} 909$ and the mouse macrophage cells may result in antibodydependent cellular phagocytosis, as some human IgG antibodies can react with mouse Fc $\gamma$ receptors [44]. Despite the fact that NSG mice harbor mutations leading to defective macrophages, other studies have shown these macrophages can impact model systems using human hematopoietic cells and have validated the use of liposomal clodronate to deplete these macrophages [35-40,43].

We hypothesized that macrophages were involved in the m909 mediated response in our in vivo system and used liposomal clodronate for depletion. Our results demonstrated that mice receiving the liposomal clodronate with m909 trended toward larger tumors compared to those receiving m909 alone, possibly indicating some impact on antibody function, however, the difference was not statistically significant. Interestingly, some mice receiving $\mathrm{m} 909$ and liposomal clodronate had tumors that were detectable on day 21 but disappeared on day 35, suggesting the efficacy of m909 in these mice. This finding correlates with our data demonstrating an initial reduction in macrophages on day 1 but failing to achieve persistent depletion with continued small doses of liposomal clodronate by day 21. If indeed mouse macrophages are playing a role in facilitating cytotoxicity of the tumors with $\mathrm{m} 909$, the normalization by day 21 may be responsible for the disappearance of these tumors. Perhaps treatment with higher dosing of the liposomal clodronate would allow for sustained macrophage depletion response yielding more informative in vivo data, however, this must be balanced with the established toxicity that NSG mice experience 
with liposomal clodronate dosing [35]. While the mechanism of action of m909 in the in vivo model is not entirely resolved, what is evident is that there is a significant impact of the antibody on reducing tumor growth in both in vitro and in vivo models, rationalizing the further development of this therapeutic approach.

In addition to direct therapy against AML, our results also demonstrate expression of FR $\beta$ on TAMs from 15 individual ovarian ascites samples as well as the ability for m909 to cause ADCC of TAMs in a dose-dependent manner. Elimination of M2 polarized macrophages from the tumor microenvironment with m909 could potentially improve the efficacy of chemotherapy or immunotherapy treatments targeting the tumor cells directly when used in combination. M2 polarized TAMs are also not unique to ovarian cancer and occur in the microenvironment of many solid cancers making their application broader [21,45]. Unfortunately, there are also challenges in replicating the tumor microenvironment and further experiments to demonstrate the efficacy of $\mathrm{m} 909$ in vivo or in combination with other therapeutic agents requires transitioning away from a human NK reconstituted mouse model, as a functional immune system is necessary to represent the tumor microenvironment.

Research in immunotherapies for various cancers has led to breakthrough treatments in some diseases with durable responses unlike any previously seen with standard chemotherapy, radiation, or surgery [46]. Our data demonstrate FR $\beta$ as a potential therapeutic target for both direct cancer therapy causing cytotoxicity to AML cells in both in vivo and in vitro models, as well as indirect therapy targeting the tumor microenvironment of solid tumors such as ovarian cancer through in vitro cytotoxicity of TAMs. The mechanism of action in the in vivo AML model remains unclear, but our data suggest that mouse macrophages may play at least a partial mechanistic role in m909 activity. Further investigation will be necessary to clarify the in vivo mechanisms of m909 activity in order to better understand how m909 might be used in the treatment of AML. Additionally, studies aimed at better understanding its application in targeting the tumor microenvironment and its potential as a dual therapeutic in the treatment of solid tumors warrant consideration.

\section{Materials and Methods}

\subsection{Antibodies}

m909 FR $\beta$ directed antibody was described earlier [27], and provided by Monojul for all in vitro and in vivo studies. Anti-CD33_PE (cat\# 366607), anti-CD14_PE-Cy7 (cat\# 367111), anti-CD34_FITC (cat\# 343603), anti-F4-80_PE-Cy7 (cat\# 123113), anti-CD11b_PE (cat\# 101207), and anti-mouse FR $\beta \_A P C$ (cat\# 153305) antibodies were ordered through Biolegend.

\subsection{Cell Lines}

All cell lines were cultured in complete media (RPMI-1640-GlutaMAX with 10\% fetal bovine serum, $100 \mathrm{U} / \mathrm{mL}$ penicillin, and $100 \mu \mathrm{g} / \mathrm{mL}$ streptomycin) at $37^{\circ} \mathrm{C}$. THP- 1 and MV4-11 cells were purchased from American Type Culture Collection and HL-60 cells were kindly provided by Gwenn Danet-Desnoyers (University of Pennsylvania). CHO-FR $\beta$ cells were a gift from the lab of Phillip Low at Purdue University and CHO-K1 cells were purchased from American Type Culture Collection. All cell lines were transduced with a lentiviral vector containing GFP and fLuc separated by a T2A ribosomal skipping element (GFP-2A-fLuc). De-identified natural killer cells and peripheral blood mononuclear cells collected from healthy donors were purchased from the University of Pennsylvania Human Immunology Core (HIC). George Coukos kindly provided the ID8 cell line. The parental ID8 line was transduced with a lentiviral construct containing mCherry (RFP) and fLuc (RFP-2A-fLuc) to create ID8-RFPfLuc. ID8-RFPfLuc cell line was then transduced with a lentiviral construct encoding murine FR $\beta$ cDNA (Origene) to produce ID8.mFR $\beta$-RFPfLuc. 


\subsection{Flow Cytometry}

m909 and human IgG1 antibody were biotinylated using the EX-Link Sulfo-NHS-LC Biotinylation Kit (Thermo Fisher Scientific). Up to $1 \times 10^{6}$ cells were labeled in $100 \mu \mathrm{L}$ staining buffer ( $2 \%$ fetal bovine serum in phosphate-buffered saline) containing relevant antibodies at $4{ }^{\circ} \mathrm{C}$. Streptavidin(SA)-allophycocyanin(APC) was used for secondary detection of FR $\beta$. Samples were also stained with other antibodies as indicated in each study as well as with the LIVE/DEAD ${ }^{\text {TM }}$ Fixable Aqua Dead cell stain. Samples were assessed by flow cytometry using a BD LSRFortessa Flow Cytometer, and results were analyzed with FlowJo 10.4.2 software.

\subsection{Antibody-Dependent Cellular Cytotoxicity (ADCC) in Cell Lines}

THP-1, MV4-11, HL-60, CHO-FR $\beta$, and CHO-K1 cells transduced with GFP-2A-fLUC lentiviral vector were used in ADCC assays. $1 \times 10^{4}$ cells were plated in triplicate in a 96 well plate in $100 \mu \mathrm{L}$ phenol-free complete media. Adherent cell lines were plated the day prior to the experiment to allow for adherence and fresh media exchanged on the day of the experiment. m909 was added at concentrations indicated in each study and incubated with cells for $20 \mathrm{~min}$. NK cells were then added at an E:T ratio of 10:1 and co-cultured overnight. Residual luciferase activity was then measured using the Extended-Glow Luciferase Reporter Assay System (Life Technologies, Carlsbad, CA, USA). Percent of lysis was calculated as follows: (100 - ((average signal antibody-treated wells)/(average signal cells alone) $\times 100)$ ).

\subsection{Cell Growth Assays}

THP-1, MV4-11, and HL-60 cells were plated at a concentration of $0.3 \times 10^{6}$ cells $/ \mathrm{mL}$ in six well plates with and without $\mathrm{m} 909$, and the growth was calculated by measuring cell counts daily. The same experiment was performed for CHO-FR $\beta$ and CHO-K1 cells except four wells with $0.5 \times 10^{5}$ cells/well were plated in 24 well plates for each cell line and one well was counted daily. All experiments were performed in triplicate.

\subsection{CDC Assays}

THP-1, HL-60, CHO-FR $\beta$, and CHO-K1 cells transduced with GFP-2A-fLUC were plated in flat-bottom 96 well plates (10,000 cells/well) with different concentrations of antibody in media containing human serum. After $3 \mathrm{~h}$ incubation at $37^{\circ} \mathrm{C}$ in a $5 \% \mathrm{CO} 2$ incubator, samples were analyzed for residual luciferase activity using the Extended-Glow Luciferase Reporter Assay System (Thermo Fisher Scientific \#T1034) as with the ADCC assays, and percent cell lysis was calculated in the same fashion

\subsection{Apoptosis Assays}

THP-1, HL-60, CHO-FR $\beta$, MV4-11, and CHO-K1 cells $\left(0.3 \times 10^{6}\right.$ cells / well $)$ in a 12 well plate were incubated in media containing $10 \mu \mathrm{g} / \mathrm{mL}$ of $\mathrm{m} 909$ for $24 \mathrm{~h}$. Samples were then stained for apoptosis markers (PE Annexin V, Biolegend \#640908 and 7-AAD, Biolegend \#420404) to detect loss of plasma membrane integrity and analyzed for percentage of cells in early and late apoptosis using BD LSRFortessa flow cytometry.

\subsection{Antibody-Dependent Cellular Cytotoxicity in AML Patient Samples}

De-identified primary AML patient samples were purchased from the Tissue Bank \& Cell Processing facility in the Stem Cell \& Xenograft Core, University of Pennsylvania. Samples were stained with fluorophore-labeled antibodies for their expression of FR $\beta$, CD34, CD33, and CD14 by flow cytometry. A sample with a higher expression of CD33 and FR $\beta$ was selected for ADCC. Samples were thawed and $3 \times 10^{4}$ cells were plated in a 96 well plate in triplicate and $\mathrm{m} 909$ was added at the specified concentrations for $20 \mathrm{~min}$. NK cells purchased from the HIC core were then added at an E:T ratio of 10:1. Following $24 \mathrm{~h}$ incubation, the cells were stained for CD33, FR $\beta$, and LIVE/DEAD TM Fixable Aqua. Brightcount counting beads were added and the total numbers of CD33+ live cells and 
CD33+/FRB+ live cells were calculated at the different antibody concentrations using flow cytometry. This technique was also performed using THP-1 cells for proof of concept.

\subsection{Antibody-Dependent Cellular Cytotoxicity in Ovarian Cancer Patient Ascites Samples}

De-identified primary ovarian cancer ascites samples were provided by the University of Pennsylvania Tumor Tissue and Biospecimen Bank. Samples were analyzed by flow cytometry for expression of FR $\beta, C D 14$, and CD11b. Patient samples used for ADCC were then sorted by $\mathrm{CD} 11 \mathrm{~b}$ expression to isolate macrophages using $\mathrm{CD} 11 \mathrm{~b}$ magnetic beads. Using the same technique as the AML samples, $3 \times 10^{4}$ cells from the CD11b positive population were plated per well in a 96 well plate in triplicate, and m909 was added at the specified concentrations for $20 \mathrm{~min}$. NK cells purchased from the HIC core were then added at an E:T ratio of 10:1. Following $24 \mathrm{~h}$ incubation, the cells were stained for CD14, FR $\beta$, and LIVE/DEAD TM Fixable Aqua. Brightcount counting beads were added and the total numbers of CD14+ live cells and CD14+/FR $\beta+$ live cells were calculated at the different antibody concentrations using flow cytometry.

\subsection{Mice}

Female NOD/SCID/ $\gamma$ chain - / - (NSG) mice that were 8 to 12 weeks old were purchased from the Stem Cell Xenograft Core. They were treated and maintained under strict pathogen-free conditions. All protocols were approved by the University of Pennsylvania Institutional Animal Care and Use Committee. THP-1 cells transduced with lentiviral GFP2A-fLuc vector were sorted by flow cytometry to obtain a $100 \%$ GFP expressing population. Cells were analyzed by flow cytometry for FR $\beta$ expression and then $2 \times 10^{6}$ cells were injected intravenously (IV) into mice on day 0 . Five mice were included in each treatment group for all except for studies in which liposomal clodronate was used. These studies included 10 mice/group, due to immediate death of some mice following IV liposomal clodronate injection in a pilot study, possibly due to injection toxicity. In studies including NK cells, NK cells were purchased from the HIC, activated with IL-2, and $2 \times 10^{6}$ cells were injected IV into the tail vein on day 2 following tumor inoculation. Antibodies were administered via intraperitoneal injection (IP) every Monday, Wednesday, and Friday for 10 doses starting on day 2 following tumor injection. For studies requiring macrophage depletion, mice were treated with liposomal clodronate. Liposomal clodronate $(5 \mathrm{mg} / \mathrm{mL})$ was purchased from Liposoma B.V. (Amsterdam, The Netherlands) and $200 \mu \mathrm{L}$ were given IV and $100 \mu \mathrm{L}$ IP on day -2 and then $25 \mu \mathrm{L}$ IV on day 1 and every 5 days until the end of antibody administration. Dosages were extrapolated from a review of the literature using liposomal clodronate in mice [30-37] and from pilot study experiments.

Mice were euthanized if they lost at least $20 \%$ of their weight, if they developed ascites or if they exhibited any sign of suffering that could not be relieved.

\subsection{Bioluminescence Imaging}

Bioluminescence imaging studies were performed using the Lumina IVIS imaging system and quantified with the Living Image Software (PerkinElmer). Mice were injected intraperitoneally with D-luciferin $(150 \mathrm{mg} / \mathrm{kg})$ and imaged under isoflurane anesthesia. Images were recorded until two consecutive images showed decreasing signal and peak signal was determined for each mouse at each designated time point. Pseudocolor images representing light intensity were generated with Living Image Software.

Supplementary Materials: The following are available online at https:/ /www.mdpi.com/article/10 .3390 /ijms22115572/s1, Supplemental Figure S1 Preclinical activity of m909 against THP-1 tumors compared to non-specific antibody in vivo. Mice were injected with $2 \times 106$ THP-1 cells expressing GFP-fLuc on day 0 and imaged weekly. They were treated with IP injection starting on day 2 every 2-3 days thereafter for 10 doses with $50 \mu \mathrm{g}$ m909, $100 \mu \mathrm{g}$ Herceptin, or PBS. The graph demonstrates the average radiance of each group at each measurement time point. Error bars represent standard error. A significant difference in average maximum radiance of $1.226 \times 10^{9}\left(95 \%\right.$ CI $1.007 \times 10^{7}-2.441$ 
$\times 10^{9}$ ) was identified on day 49 between the $50 \mu \mathrm{g}$ m909 group and the PBS group. There was no difference between the $100 \mu \mathrm{g}$ Herceptin and PBS group.

Author Contributions: A.G.R., J.M.R., P.S., C.N.-N. and D.J.P.J. contributed to the study concept and design. A.G.R., P.S. and A.R.-G. performed material preparation, data collection, and analysis for in vitro studies. A.G.R., M.A.P. and A.R.-G. performed material preparation, data collection, and analysis for the in vivo studies. A.G.R. wrote the first draft of the manuscript and all authors contributed to editing and approval of the final manuscript. All authors have read and agreed to the published version of the manuscript.

Funding: This research was sponsored by HuLow Medical and Monojul LLC.

Institutional Review Board Statement: De-identified primary ovarian cancer ascites samples were provided by the Penn Ovarian Cancer Research Center Tumor BioTrust. Investigations were carried out following the rules of the Declaration of Helsinki of 1975 (https: / /www.wma.net/what-we-do/ medical-ethics/declaration-of-helsinki/ accessed on 24 May 2021), revised in 2013. According to point 23 of this declaration. The animal studies were performed according to the guidelines of the University of Pennsylvania Institutional Animal Care and Use Committee (protocol 805773, approved 14 March 2018).

Data Availability Statement: There are no large datasets used in this manuscript and all raw data is available upon request.

Acknowledgments: The authors acknowledge support from the University of Pennslyvania's Gynecologic Oncology Fellowship Program, the Sandy Rollman Ovarian Cancer Foundation, and the Ovarian Cancer Research Alliance. We thank the Small Animal Imaging Core Facility, the Stem Cell and Xenograft Core, the Human Immunology Core, and the OCRC Tumor BioTrust at the University of Pennsylvania for their technical services.

Conflicts of Interest: Daniel J. Powell holds patents in the area of anti-FR $\beta$ CAR T cell therapy. No other authors have any conflicts of interest to disclose.

\section{References}

1. Zhang, H.; Chen, J. Current status and future directions of cancer immunotherapy. J. Cancer 2018, 9, 1773-1781. [CrossRef] [PubMed]

2. Coney, L.R.; Tomassetti, A.; Carayannopoulos, L.; Frasca, V.; Kamen, B.A.; Colnaghi, M.I.; Zurawski, V.R., Jr. Cloning of a tumor-associated antigen: MOv18 and MOv19 antibodies recognize a folate-binding protein. Cancer Res. 1991, 51, 6125-6132. [PubMed]

3. Ross, J.F.; Wang, H.; Behm, F.G.; Mathew, P.; Wu, M.; Booth, R.; Ratnam, M. Folate receptor type beta is a neutrophilic lineage marker and is differentially expressed in myeloid leukemia. Cancer 1999, 85, 348-357. [CrossRef]

4. Ross, J.F.; Chaudhuri, P.K.; Ratnam, M. Differential regulation of folate receptor isoforms in normal and malignant tissues in vivo and in established cell lines. Physiol. Clin. Implic. Cancer 1994, 73, 2432-2443. [CrossRef]

5. Kandalaft, L.E.; Powell, D.J.; Coukos, G.; Coukos, G. A phase I clinical trial of adoptive transfer of folate receptor-alpha redirected autologous T cells for recurrent ovarian cancer. J. Transl. Med. 2012, 10, 157. [CrossRef]

6. Kershaw, M.H.; Westwood, J.A.; Parker, L.L.; Wang, G.; Eshhar, Z.; Mavroukakis, S.A.; White, D.E.; Wunderlich, J.R.; Ca-nevari, S.; Rogers-Freezer, L.; et al. A phase I study on adoptive immunotherapy using gene-modified T cells for ovarian cancer. Clin. Cancer Res. 2006, 12, 6106-6115. [CrossRef] [PubMed]

7. Vergote, I.; Armstrong, D.; Scambia, G.; Teneriello, M.; Sehouli, J.; Schweizer, C.; Weil, S.C.; Bamias, A.; Fujiwara, K.; Ochiai, K.; et al. A Randomized, Double-Blind, Placebo-Controlled, Phase III Study to Assess Efficacy and Safety of Weekly Farletuzumab in Combination With Carboplatin and Taxane in Patients With Ovarian Cancer in First Platinum-Sensitive Relapse. J. Clin. Oncol. 2016, 34, 2271-2278. [CrossRef]

8. Kim, K.H.; Jelovac, D.; Armstrong, D.K.; Schwartz, B.; Weil, S.C.; Schweizer, C.; Alvarez, R.D. Phase, 1b safety study of farletuzumab, carboplatin and pegylated liposomal doxorubicin in patients with platinum-sensitive epithelial ovarian cancer. Gynecol. Oncol. 2016, 140, 210-214. [CrossRef]

9. Armstrong, D.K.; White, A.J.; Weil, S.C.; Phillips, M.; Coleman, R.L. Farletuzumab (a monoclonal antibody against folate receptor alpha) in relapsed platinum-sensitive ovarian cancer. Gynecol. Oncol. 2013, 129, 452-458. [CrossRef]

10. Sasaki, Y.; Miwa, K.; Yamashita, K.; Sunakawa, Y.; Shimada, K.; Ishida, H.; Hasegawa, K.; Fujiwara, K.; Kodaira, M.; Fujiwara, Y.; et al. A phase I study of farletuzumab, a humanized anti-folate receptor $\alpha$ monoclonal antibody, in patients with solid tumors. Investig. New Drugs 2015, 33, 332-340. [CrossRef]

11. Konner, J.A.; Bell-McGuinn, K.M.; Sabbatini, P.; Hensley, M.L.; Tew, W.P.; Pandit-Taskar, N.; Vander Els, N.; Phillips, M.D.; Schweizer, C.; Weil, S.C.; et al. Farletuzumab, a Humanized Monoclonal Antibody against Folate Receptor $\alpha$, in Epithelial Ovarian Cancer: A Phase I Study. Clin. Cancer Res. 2010, 16, 5288-5295. [CrossRef] [PubMed] 
12. Farrell, C.; Schweizer, C.; Wustner, J.; Weil, S.; Namiki, M.; Nakano, T.; Nakai, K.; Phillips, M.D. Population pharmacokinetics of farletuzumab, a humanized monoclonal antibody against folate receptor alpha, in epithelial ovarian cancer. Cancer Chemother. Pharmacol. 2012, 70, 727-734. [CrossRef] [PubMed]

13. Martin, L.P.; Konner, J.A.; Moore, K.N.; Seward, S.M.; Matulonis, U.A.; Perez, R.P.; Su, Y.; Berkenblit, A.; Ruiz-Soto, R.; Birrer, M.J. Characterization of folate receptor alpha $(\mathrm{FR} \alpha)$ expression in archival tumor and biopsy samples from relapsed epithelial ovarian cancer patients: A phase I expansion study of the FR $\alpha$-targeting antibody-drug conjugate mirvetuximab soravtansine. Gynecol. Oncol. 2017, 147, 402-407. [CrossRef]

14. Moore, K.N.; Martin, L.P.; O’Malley, D.M.; Matulonis, U.A.; Konner, J.A.; Perez, R.P.; Bauer, T.M.; Ruiz-Soto, R.; Birrer, M.J. Safety and Activity of Mirvetuximab Soravtansine (IMGN853), a Folate Receptor Alpha-Targeting Antibody-Drug Conjugate, in Platinum-Resistant Ovarian, Fallopian Tube, or Primary Peritoneal Cancer: A Phase I Expansion Study. J. Clin. Oncol. 2017, 35, 1112-1118. [CrossRef]

15. Moore, K.N.; Borghaei, H.; O’Malley, D.M.; Jeong, W.; Seward, S.M.; Bauer, T.M.; Perez, R.P.; Matulonis, U.A.; Running, K.L.; Zhang, X.; et al. Phase 1 dose-escalation study of mirvetuximab soravtansine (IMGN853), a folate receptor $\alpha$-targeting antibody-drug conjugate, in patients with solid tumors. Cancer 2017, 123, 3080-3087. [CrossRef] [PubMed]

16. Shen, F.; Ross, J.F.; Wang, X.; Ratnam, M. Identification of a novel folate receptor, a truncated receptor, and receptor type .beta. in hematopoietic cells: cDNA cloning, expression, immunoreactivity, and tissue specificity. Biochemistry 1994, 33, 1209-1215. [CrossRef] [PubMed]

17. Wang, H.; Zheng, X.; Behm, F.G.; Ratnam, M. Differentiation-independent retinoid induction of folate receptor type beta, a potential tumor target in myeloid leukemia. Blood 2000, 96, 3529-3536. [CrossRef]

18. Mills, C.D.; Kincaid, K.; Alt, J.M.; Heilman, M.J.; Hill, A.M. M-1/M-2 Macrophages and the Th1/Th2 Paradigm. J. Immunol. 2000, 164, 6166-6173. [CrossRef]

19. Mantovani, A.; Sozzani, S.; Locati, M.; Allavena, P.; Sica, A. Macrophage polarization: Tumor-associated macrophages as a paradigm for polarized M2 mononuclear phagocytes. Trends Immunol. 2002, 23, 549-555. [CrossRef]

20. Yuan, X.; Zhang, J.; Li, D.; Mao, Y.; Mo, F.; Du, W.; Ma, X. Prognostic significance of tumor-associated macrophages in ovarian cancer: A meta-analysis. Gynecol. Oncol. 2017, 147, 181-187. [CrossRef]

21. Zhang, Q.W.; Liu, L.; Gong, C.Y.; Shi, H.S.; Zeng, Y.H.; Wang, X.Z.; Zhao, Y.W.; Wei, Y.Q. Prognostic Significance of TumorAssociated Macrophages in Solid Tumor: A Meta-Analysis of the Literature. PLoS ONE 2012, 7. [CrossRef]

22. Lan, C.; Huang, X.; Lin, S.; Huang, H.; Cai, Q.; Wan, T.; Lu, J.; Liu, J. Expression of M2-polarized macrophages is associated with poor prognosis for advanced epithelial ovarian cancer. Technol. Cancer Res. Treat. 2013, 12, 259-267. [CrossRef]

23. Mhawech-Fauceglia, P.; Wang, D.; Ali, L.; Lele, S.; Huba, M.A.; Liu, S.; Odunsi, K. Intraepithelial T cells and tumor-associated macrophages in ovarian cancer patients. Cancer Immun. 2013, 13, 1-6. [PubMed]

24. Kawamura, K.; Komohara, Y.; Takaishi, K.; Katabuchi, H.; Takeya, M. Detection of M2 macrophages and colony-stimulating factor 1 expression in serous and mucinous ovarian epithelial tumors. Pathol. Int. 2009, 59, 300-305. [CrossRef]

25. Wan, T.; Liu, J.H.; Zheng, L.M.; Cai, M.Y.; Ding, T. Prognostic significance of tumor-associated macrophage infiltration in advanced epithelial ovarian carcinoma. Chin. J. Cancer 2009, 28, 268-271.

26. Puig-Kröger, A.; Sierra-Filardi, E.; Domínguez-Soto, A.; Samaniego, R.; Corcuera, M.T.; Gómez-Aguado, F.; Ratnam, M.; SánchezMateos, P.; Corbí, A.L. Folate receptor beta is expressed by tumor-associated macrophages and constitutes a marker for M2 anti-inflammatory/regulatory macrophages. Cancer Res. 2009, 69, 9395-9403. [CrossRef] [PubMed]

27. Feng, Y.; Shen, J.; Streaker, E.D.; Lockwood, M.; Zhu, Z.; Low, P.S.; Dimitrov, D.S. A folate receptor beta-specific human monoclonal antibody recognizes activated macrophage of rheumatoid patients and mediates antibody-dependent cell-mediated cytotoxicity. Arthritis Res. Ther. 2011, 13. [CrossRef] [PubMed]

28. Lynn, R.C.; Feng, Y.; Schutsky, K.; Poussin, M.; Kalota, A.; Dimitrov, D.S.; Powell, D.J., Jr. High-affinity FR $\beta$-specific CAR T cells eradicate AML and normal myeloid lineage without HSC toxicity. Leukemia 2016, 30, 1355-1364. [CrossRef] [PubMed]

29. Lynn, R.C.; Poussin, M.; Kalota, A.; Feng, Y.; Low, P.S.; Dimitrov, D.S.; Powell, D.J., Jr. Targeting of folate receptor $\beta$ on acute myeloid leukemia blasts with chimeric antigen receptor-expressing T cells. Blood 2015, 125, 3466-3476. [CrossRef] [PubMed]

30. Pan, X.Q.; Zheng, X.; Shi, G.; Wang, H.; Ratnam, M.; Lee, R.J. Strategy for the treatment of acute myelogenous leukemia based on folate receptor $\beta$-targeted liposomal doxorubicin combined with receptor induction using all-trans retinoic acid. Blood 2002, 100, 594-602. [CrossRef] [PubMed]

31. Nagai, T.; Tanaka, M.; Tsuneyoshi, Y.; Xu, B.; Michie, S.A.; Hasui, K.; Hirano, H.; Arita, K.; Matsuyama, T. Targeting tumorassociated macrophages in an experimental glioma model with a recombinant immunotoxin to folate receptor $\beta$. Cancer Immunol. Immunother. 2009, 58, 1577-1586. [CrossRef] [PubMed]

32. Chen, B.; Fan, W.; Zou, J.; Zhang, S.; He, J.; Shu, C.; Zhao, G.; Sun, T.; Hu, Z.; Yang, Y.G. Complement Depletion Improves Human Red Blood Cell Reconstitution in Immunodeficient Mice. Stem Cell Rep. 2017, 9, 1034-1042. [CrossRef] [PubMed]

33. Shultz, L.D.; Schweitzer, P.A.; Christianson, S.W.; Gott, B.; Schweitzer, I.B.; Tennent, B.; McKenna, S.; Mobraaten, L.; Rajan, T.V.; Greiner, D.L. Multiple defects in innate and adaptive immunologic function in NOD/LtSz-scid mice. J. Immunol. 1995, 154, 180-191. [PubMed]

34. Van Rooijen, N.; Hendrikx, E. Liposomes for specific depletion of macrophages from organs and tissues. Methods Mol. Biol. 2010, 605, 189-203. [CrossRef] 
35. Van Rooijen, N.; Sanders, A. Liposome mediated depletion of macrophages: Mechanism of action, preparation of liposomes and applications. J. Immunol. Methods 1994, 174, 83-93. [CrossRef]

36. Moreno, A.; Badell, E.; Van Rooijen, N.; Druilhe, P. Human malaria in immunocompromised mice: New in vivo model for chemotherapy studies. Antimicrob. Agents Chemother. 2001, 45, 1847-1853. [CrossRef]

37. Badell, E.; Pasquetto, V.; Van Rooijen, N.; Druilhe, P. A mouse model for human malaria erythrocytic stages. Parasitol. Today 1995, 11, 235-237. [CrossRef]

38. Badell, E.; Oeuvray, C.; Moreno, A.; Soe, S.; van Rooijen, N.; Bouzidi, A.; Druilhe, P. Human malaria in immunocompromised mice: An in vivo model to study defense mechanisms against Plasmodium falciparum. J. Exp. Med. 2000, 192, 1653-1660. [CrossRef]

39. Hu, Z.; Van Rooijen, N.; Yang, Y.-G. Macrophages prevent human red blood cell reconstitution in immunodeficient mice. Blood 2011, 118, 5938-5946. [CrossRef]

40. Fraser, C.C.; Chen, B.P.; Webb, S.; van Rooijen, N.; Kraal, G. Circulation of human hematopoietic cells in severe combined immunodeficient mice after Cl2MDP-liposome-mediated macrophage depletion. Blood 1995, 86, 183-192. [CrossRef]

41. American Cancer Society Cancer Facts and Figures 2020. Available online: https://www.cancer.org/content/dam/cancer-org/ research/cancer-facts-and-statistics / annual-cancer-facts-and-figures/2020/cancer-facts-and-figures-2020.pdf (accessed on 9 May 2020).

42. Döhner, H.; Weisdorf, D.J.; Bloomfield, C.D. Acute Myeloid Leukemia. N. Engl. J. Med. 2015, 373, 1136-1152. [CrossRef] [PubMed]

43. Verstegen, M.M.A.; van Hennik, P.B.; Terpstra, W.; van den Bos, C.; Wielenga, J.J.; van Rooijen, N.; Ploemacher, R.E.; Wagemaker, G.; Wognum, A.W. Transplantation of Human Umbilical Cord Blood Cells in Macrophage-Depleted SCID Mice: Evidence for Accessory Cell Involvement in Expansion of Immature CD34+CD38-Cells. Blood 1998, 91, 1966-1976. [CrossRef] [PubMed]

44. Dekkers, G.; Bentlage, A.E.H.; Stegmann, T.C.; Howie, H.L.; Lissenberg-Thunnissen, S.; Zimring, J.; Rispens, T.; Vidarsson, G. Affinity of human IgG subclasses to mouse Fc gamma receptors. mAbs 2017, 9, 767-773. [CrossRef] [PubMed]

45. Rodriguez-Garcia, A.; Lynn, R.C.; Poussin, M.; Eiva, M.A.; Shaw, L.C.; O'Connor, R.S.; Minutolo, N.G.; Casado-Medrano, V.; Lopez, G.; Matsuyama, T.; et al. CAR-T cell-mediated depletion of immunosuppressive tumor-associated macrophages promotes endogenous antitumor immunity and augments adoptive immunotherapy. Nat. Commun. 2021, 12, 877. [CrossRef] [PubMed]

46. Maude, S.L.; Laetsch, T.W.; Buechner, J.; Rives, S.; Boyer, M.; Bittencourt, H.; Bader, P.; Verneris, M.R.; Stefanski, H.E.; Myers, G.D.; et al. Tisagenlecleucel in children and young adults with B-cell lymphoblastic leukemia. N. Engl. J. Med. 2018, 378, 439-448. [CrossRef] [PubMed] 